\title{
Resilience, Leadership and Female Entrepreneurship within the Context of SMEs: Evidence from Latin America
}

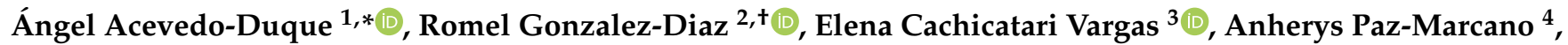

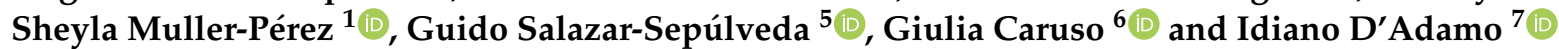

check for

updates

Citation: Acevedo-Duque, Á.; Gonzalez-Diaz, R.; Vargas, E.C.; Paz-Marcano, A.; Muller-Pérez, S.; Salazar-Sepúlveda, G.; Caruso, G.; D'Adamo, I. Resilience, Leadership and Female Entrepreneurship within the Context of SMEs: Evidence from Latin America. Sustainability 2021, 13, 8129. https://doi.org/10.3390/ su13158129

Academic Editor: Andrea Appolloni

Received: 15 June 2021

Accepted: 14 July 2021

Published: 21 July 2021

Publisher's Note: MDPI stays neutral with regard to jurisdictional claims in published maps and institutional affiliations.

Copyright: (C) 2021 by the authors Licensee MDPI, Basel, Switzerland. This article is an open access article distributed under the terms and conditions of the Creative Commons Attribution (CC BY) license (https:/ / creativecommons.org/licenses/by/ $4.0 /)$.
1 Public Policy Observatory, Faculty of Business and Administration, Universidad Autónoma de Chile, Santiago 7500912, Chile; sheyla.muller@uautonoma.cl

2 Centro Internacional de Investigación y Desarrollo (CIID), Montería 230001, Colombia; director@ciid.com.co

3 Faculty of Health Sciences, Universidad Nacional Jorge Basadre Grohmann, Tacna 23000, Peru; ecachicatariv@unjbg.edu.pe

4 Programa de Administración de Empresas, Facultad de Ciencias Económicas y Administrativas, Universidad de La Guajira, Riohacha 440001, Colombia; aipaz@uniguajira.edu.co

5 Departamento de Ingeniería Industrial, Facultad de Ingeniería, Universidad Católica de la Santísima Concepción, Concepción 4090541, Chile; gsalazar@ucsc.cl

6 Department of Neuroscience, Imaging and Clinical Sciences, “G. d'Annunzio" University of Chieti-Pescara, 66100 Chieti, Italy; giulia.caruso@unich.it

7 Department of Computer, Control and Management Engineering, Sapienza University of Rome, Via Ariosto 25, 00185 Rome, Italy; idiano.dadamo@uniroma1.it

* Correspondence: angel.acevedo@uautonoma.cl

$+\quad$ This work is dedicated to the memory of a young and promising researcher Romel Gonzalez-Diaz. Leave it to us to promote sustainability in all parts of the world. We are grateful for your insights.

\begin{abstract}
The purpose of this article is to analyze resilient female leadership as a sustainable promoter of business excellence in small and medium-sized Wayuu handicraft marketing enterprises. The present study uses a quantitative methodology with a non-experimental cross-sectional field design, with an analysis and interpretation of the data provided by the surveyed subjects. A 33-item questionnaire with multiple response options is applied. The population consists of 110.012 eradicated women. A probabilistic sampling technique is applied with a margin of error of $5 \%$ and a confidence level of $95 \%$, for a total of 383 Wayuu women entrepreneurs in the Department of La Guajira, Colombia. Our findings explain that female leadership transcends the boundaries of business management, being present in both small and medium enterprises (SMEs). This study confirms the positive relationship between sustainability and resilience in the Wayuu handicrafts market, being women who turn their actions into success factors by working with women who show technical, conceptual, and human skills.
\end{abstract}

Keywords: women's leadership; America Latina; small and medium-sized enterprises; resilience; sustainability

\section{Introduction}

Ending all forms of discrimination against women and girls is a fundamental duty to preserve human rights and IT is also crucial for sustainable development [1]. According to the United Nations Development Programme (UNDP), gender equality is a central issue. Moreover, we have witnessed remarkable progress in the last 20 years. Female schooling has increased, compared to 15 years ago, and most regions have reached gender parity in primary education. However, although there are more women than ever before in the labor market, in some regions significant inequalities still persist and women's labor rights are still not the same as those of their male counterparts [2]. Violence and sexual exploitation, unequal sharing of unpaid work-both domestic and care work-and discrimination in decision-making remain major obstacles. 
Climate change and disasters continue to have a disproportionate impact on women and children, including conflict and migration [3]. Ensuring universal access to reproductive and sexual health and granting equal rights to women in accessing economic resources, such as land and property, are critical in order to achieve this goal [4]. Today, more women than ever are holding public office. However, encouraging more women to become leaders will help to achieve greater gender equality.

To achieve the intended objectives in organizations, it is necessary to consider some elements that are capable of producing business excellence, and which translate themselves into the coordination of various factors, such as human, financial, material, economic, and technological factors [5]. These factors promote the organization of work activities that are able to create value through the creation of teamworks, which allow one to unify efforts and apply strategies to achieve common objectives. In addition, they are able to facilitate the articulation of business functions and to strengthen the company's presence in the market, creating competitive advantages. Sustainability can create a competitive advantage when the human component plays a key role [6].

Organizations are subject to periods of transition due to external environment dynamics [7]. Consequently, they can adapt and take into consideration those changes and trends that are necessary to be competitive in the environment in which they exchange their goods and services. The management of entrepreneurial activities is inescapable [8-10], and it requires the coordination of individual efforts. These ones converge in shared commitments, i.e., company-collaborators and vice versa, which guide actions in order to achieve the desired objectives. However, the way to get the expected results remains a challenge in business management and in business organization. It finally results in corporate social responsibility (CSR) because of its impact on the society in which it allocates its goods and services [8].

The new organizations are the ones who should coordinate their missionary activities in various units and the essential functions of the organizational structure, minimizing the risk impact [11]. The global market requires changes in the managerial paradigm, in order to obtain new managerial approaches and to promote business cohesion, through the participation of all employees. For some authors, new managerial behavior in organizations must be different from the traditional behavior, more based on a transformational style, and it is necessary to move from hierarchical and rigid organizations to more flexible horizontal ones, which have a greater capacity to adapt to changes occurring in the working world [12].

Thus, business management has to look for qualified collaborators whose competencies are suitable for managerial positions, contributing to image, reputation, and profitability, in order to position companies in those markets where they are offering their products, goods, and services [13,14]. Managerial leadership contributes to the excellence of its missionary processes, leaving behind the old paradigms of exclusivity of organizational management, which are usually occupied by men. Thus, emerging female characteristics are dominance, strength, robustness, intelligence, perseverance, and responsibility. These characteristics create a sense of equality in business management [15].

However, in world business scenarios, this trend and change of paradigm of business management has led to some debates about which are the gender skills required to occupy management positions in organizations. It is essential to know the opinions of the specialists on this subject. They underline the importance of knowing which are the essential characteristics, skills, abilities, and competencies of a manager. They should take into account the qualities that inspire credibility, trust, and reputation in the exercise of their functions, and their projection and acceptance in the environment, both internally and externally of the market where they participate $[2,16]$.

According to some authors $[17,18]$, the leader figure is crucial in any field, since his/her actions are an essential factor in guiding collaborators to achieve common objectives. These innovative trends of maintaining sustainability and stability in the market [19] also involve small and medium enterprises, mainly in Colombia. 
Therefore, we considered marketers or micro-entrepreneurs of Wayuu handicrafts in the unique tourist and cultural district of Riohacha, in Colombia. The focus is on those sectors where women's leadership enabled excellent performance from an economic perspective [20,21]. In particular, these works highlighted how women's rights, as well as important professional and managerial insight, made it possible to change for the better a working environment excessively characterized by male stereotypes. However, there are situations in which it is not difficult to avoid such kinds of characterizations that label the company's management, especially with regards to the current demands of adaptation in the world [20].

Since our objective is to understand how different markets are moving towards a sustainable revolution, the three hypotheses of this research, which will be answered through the literature and our results, are:

- Hypothesis 1 (H1). Leadership characteristics influence female leadership in those SMEs that are dedicated to the organization of Wayuu handicrafts.

- Hypothesis 2 (H2). Leadership styles are related to female leadership in those SMEs that are dedicated to Wayuu handicrafts.

- Hypothesis 3 (H3). Leadership skills influence the development of female leadership in Wayuu handicraft marketing SMEs.

We investigated how different stakeholder perspectives need to be combined [22]. The focus is on how a company can create competitive advantage and on how human and organizational factors are able to influence this epochal change. In this context, the synergy between the concepts of sustainability and resilience represents an element of analysis to be investigated since it can harmonize the different factors that determine the success of a company in a market [23]. The literature shows a positive relationship between sustainability and resilience in the fashion industry [7]. Given the heterogeneity and diversity of Latin America as a geographical area [24,25], the interest of this research is to analyze resilient female leadership as a sustainable factor that promotes business excellence in small and medium-sized Wayuu handicraft co-marketing enterprises. We propose three study hypotheses, and we underline that the conclusions obtained in this paper can be applied to other regions and continents of the planet, based on grounded theory. The results are shown and discussed in the following sections.

\section{Background}

Hypothesis 1 (H1). Leadership characteristics influence female leadership in those SMEs dedicated to the organization of Wayuu handicrafts.

\subsection{Resilient Female Leadership and Its Distinctive Approach to Manage Small and Medium-Sized Wayuu Handicraft Enterprises}

Worldwide, the women inclusion in management positions has an important significance. The focus is on promoting sustainable leadership and human capital with competencies that can boost sustainable and resilient development in organizations [5]. However, there are still gaps in Latin America, specifically in Colombia, where women, despite being resilient and covering some senior management positions, still have little presence in the system. Some studies claim that when women cover management positions it is possible to increase the diversity of perspectives and opinions in companies [20,22]. According to the official World Bank data, in Colombia in the last 10 years the women labor participation rate ( $\%$ of the female population between $15-64$ years old) has been equal to $43.39 \%$, with only the $20 \%$ covering top management positions (see Figure 1 ). The estimate has been modeled by the ILO. 


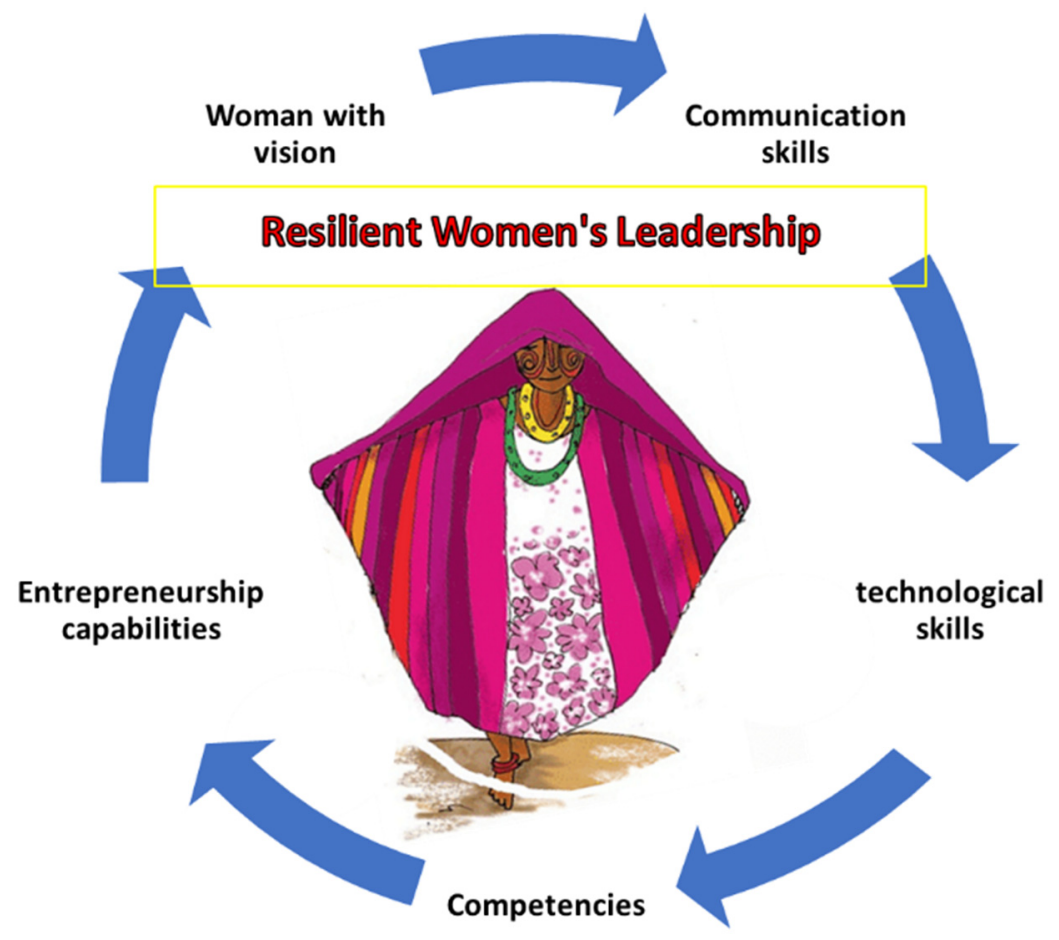

Figure 1. Resilient Women's Leadership. Source: own elaboration.

In those family businesses that are characterized by the Wayuu indigenous culture, women have been playing an invisible role for many years, as can be seen in the literature [26]. It has been shown that very few women reach high positions in the management bodies of these types of companies. However, the number of women in top management and board positions has been slowly increasing over the last decade [27]. Female leadership is a trending topic in business management and in those ventures that empower the sustainable education and culture. They became a focus of attention in the management of work processes, with the aim to promote shared performance and motivate collaborators in the development of their functions. It is possible, through open dialogue, effective communication, and the exposure of ideas in particular situations, to achieve teamwork of excellence and quality [28].

However, there is still a cultural barrier that leads one to encounter different inconveniences, which, in many cases, can become real problems, generating conflicts and wasting time, especially when it comes to breaking sociocultural patterns in which the male figure prevails as an icon of business management.

Leadership in Wayuu societies faces different situations associated with gender, which are based on a culture represented by ancestral teaching [29]. The person, as a sociable entity, desires impartiality and objectivity in acting, for him/herself, but also to relate positively with others, while, in reality, often there are attitudes of rivalry and low human sense in interactions with others.

From these perspectives, it seems that leadership implies intuition as an internal dynamic, which is useful to consolidate the relationship of people with themselves and with others. Also crucial is the ability to behave and interact in society [30], depending on gender typology. Leadership, in fact, has caused a division of labor, a separation of spaces, which has led to changes in certain expectations concerning characteristics, styles, skills, abilities, skills, resilience, and aptitudes in terms of management related to a certain gender (the female one) [31,32]. Female performance has been stereotyped by traditional roots that, until today, have been difficult to eradicate in daily practices and in the world vision. The current reality demands equality, commitment, and excellence at work where each human being can grow professionally without discrimination. 
It is worth mentioning that several authors agree on the praxis of resilient leadership as a business trend and as a critical factor to achieve success [33-35] and to obtain spaces in the international economy. This perspective considers resilient female leadership as a way to change the business paradigms rooted in the figure of male gender management, thus evidencing the position of taking women out of their role as being only dedicated to domestic life, to transform the changes as women with executive visions interested in solving the problems of business and social environments. In this way, they will play a key role, assuming from their ideas consonant answers, sustainable to the active reality of the environment, creating strategies to find solutions to elusive issues, so that their role gives way to the fulfillment of various functions in today's society (see Figure 1), being co-participants in the transformation of an egalitarian society.

In this framework, we highlight the evolution of women in society, from their work in business management, to being resilient, to having new approaches in leadership style $[8,36]$; women using this resilient approach assume various ways of managing to achieve their intended objectives and insert their values as people in a dynamic and proactive way, to ensure business competitiveness and increase the commitment and loyalty of their people [37]. In addition, we consider some authors who inserted the image of resilient female leadership in the business context, to break the limiting paradigm of the glass ceiling $[33,38]$. Women entrepreneurs are seen with leadership characteristics, styles, and skills that empower them on the road to success and in their lives. Thus, it has been possible to verify, from the research results, the role of women to exercise leadership in the management of companies.

Hypothesis 2 (H2). Leadership styles are related to female leadership in SMEs marketing Wayúu handicrafts.

\subsection{Characteristic Styles of Female Leadership in the Management of Small and Medium-Sized} Enterprises That Market Wayuu Handicrafts

Female leadership is characterized by initiative, by effectiveness in building work teams, and by the ability to make decisions in times of crisis. Furthermore, it acts with resilience, it is characterized by self-development and orientation to results, and it shows high integrity and honesty. It develops, inspires, and motivates others; it builds leadership and relationships; it sets ambitious goals, collaboration, and teamwork; it connects with the outside world; it communicates powerfully and prolifically; and it analyzes and solves problems. Moreover, it is characterized by speed of leadership and innovation [36]. Therefore, each company should have the priority to develop, train, and give the opportunity to a woman to lead employees. Thus, it is necessary to demonstrate that female leadership, in an everyday sense, is characterized by more than a domestic life and by more than a maternal role. On many occasions, women are seen as responsible human beings [39], committed to their domestic functions, transforming this vision with a managerial training as a manager, who plays a role of responsibility through various personal characteristics, such as organizing herself, the ability to plan family activities, and facing to adversity [40].

Women have the ability to plan and are able to preserve their balance in difficult situations, among other things. In addition, they have strong leadership skills, such as the ability to negotiate, supervise, teach, guide, direct, establish conflict control mechanisms, and show an objective and impartial stance, which makes them authentic human beings in society.

Some authors highlight the following leadership styles that influence the optimal development of organizational processes: coercive, participative, helmsman, coaching, visionary [41,42]. According to the criteria of another work [43], feminine characteristics at work can be related to leadership through the attitude of inclusion, and confidence in one's own charisma, capacity, and interpersonal skills to influence others. On the other hand, other authors define different attributes such as dexterity, capacity, expertise, art, mastery, techno-science, poise, and experience; the person with such attributes is a very committed guide, as they tend to increase the ability to handle situations or interact with people [44]. 
Hypothesis 3 (H3). Leadership skills influence the development of female leadership in Wayúu handicraft marketing SMEs.

2.3. Skills Developed by Women Entrepreneurs in the Management of Small and Medium-Sized Wayuu Handicraft Trading Companies

Despite social and business issues, women in their leading role and their working function apply their following skills, both conceptual, technical, and human [45], in order to contribute to an excellent performance in their working places:

- Conceptual ability: The leader is able to see the organization as a whole, in which the parts complement each other; in this case, it regards the relationship of the company with another one. According to authors' criteria, conceptual ability is the mental capacity to coordinate diverse interests and activities. It means having the capacity of abstract thinking, of analyzing information, and of establishing connections between data [43,46]; therefore, the manager must achieve critical thinking and conceptualize things with respect to how they could be. The authors highlight how the practice of the analyzed companies shows the relational abilities and the capacity of creating alliances, in order to work with strategies favoring the common good.

- Technical competencies: Technical competencies are the set of knowledge, experiences, and skills that are necessary to adequately fulfill the requirements of their positions [43,47]. The skills represented by technical competencies, which are associated with tools, procedures, and techniques specific to their situation of specialization, are necessary to master their work. In the analyzed companies, the technical competencies of female leadership derive from their practical experience and from the setting of strategies to carry out the work plan.

- Human competencies: Human skills that the leader has to master to perceive the strengths of the human talents in the organization. Some authors underline that human relations skills focus on the aptitude to work together, to understand, and to motivate people in the workplace $[43,48]$. The importance of assertive and effective communication is emphasized, through a vision shared with collaborators, by listening to what they have to say and by guiding, facilitating, and supporting people in the workplace.

\subsection{Leadership Styles in the Entrepreneurship of Women Marketers of Wayuu Handicrafts}

Industry and associated technological change result in modifications that are difficult to reach. They not only have an impact on the organization of a company but also on the people within it [49]. The dynamics of the business environment require the development of collective learning processes able to deploy actions aimed at achieving efficient leadership management in SMEs. They go beyond the search for adapting or managing leadership styles. Enterprises that identify with this behavior are the so-called "learning organizations", and they are recognized as entities that deliberately adopt structures and strategies to stimulate a helping and learning approach in their collaborators and that are continuously promoting actions aimed at improving their organizational learning capacity [4].

The end of the post-managerial era has given rise to leadership, the purpose of which, according to [50], relates to the "implementation of deliberate change" and is developed through influencing and motivating followers. In the case of Wayuu women craft entrepreneurs, they are characterized by assuming visionary leadership styles that inspire and help their generations to continue promoting their traditions in a sustained way, promoting resilient actions both in individual, team, and organizational learning, in order that such enhanced learning increases the performance of the women of this culture for generations [51].

Thus, Wayuu women are characterized by leadership styles such as Coercive Leadership, which develops a leadership style in which the informed Wayuu woman has a certain degree of coercive influence over her followers (family, collaborators, clients, among 
others) $[52,53]$. The participative leadership style is also characterized by Wayuu women involving subordinates in decision making, listening to their suggestions, and integrating them into the set of decisions that are daily taken in an organization [54].

Helping leadership is one of the most important leadership styles in the Wayuu culture as it is constantly looking for ways to integrate people into organizational processes [49]. This leader is convinced that the only way to achieve results is with the commitment to help people with the firm's activities. In terms of coaching style, the leader acts more like a counsellor than a traditional boss. He listens to people's concerns and hopes and shares his own [55]. Finally, visionary leadership is characterized by the construction of a company vision. It develops organizational cohesion in the pursuit of it. Leaders who use this style help followers to identify their strengths and weaknesses, adjusting them to be resilient agents of change in their professional and personal aspirations.

\section{Materials and Methods}

This article is based on scientific criteria, and on a quantitative paradigm, consisting in the analysis and the interpretation of female leadership data, elaborated from their competencies in Wayuu handicraft marketing companies [17,37].

This study uses a quantitative methodology, under a non-experimental and transactional field design, and a survey is applied (a 33-item questionnaire with a Likert scale and a Cronbach's Alpha coefficient of 0.906) taking into account some characteristics, styles, and competencies of Wayuu women [49].

These results have been collected on the basis of the opinion of the involved population and of their skills in small and medium-sized companies that trade Wayuu handicrafts in La Guajira Colombia. It is a field study since the data provided by the respondents express their perception about the female leadership variable (See Table 1).

Table 1. Data interpretation. Source: Own elaboration.

\begin{tabular}{cc}
\hline Rank & Interpretation \\
\hline Min-1.80 & Variable: Female Leadership \\
$1.81-2.60$ & Deficient presence of female leadership. \\
$2.61-3.40$ & Low presence of female leadership \\
$3.41-4.20$ & The regular presence of female leadership. \\
$4.21-$ Max & High presence of female leadership. \\
& Very high presence of female leadership. \\
Min-1.80 & Dimension: Characteristics \\
$1.81-2.60$ & Very few leadership characteristics. \\
$2.61-3.40$ & Few leadership characteristics \\
$3.41-4.20$ & Some leadership characteristics \\
$4.21-$ Max & Many leadership characteristics. \\
& Too many leadership characteristics. \\
Min-1.80 & Coercive \\
$1.81-2.60$ & Participatory \\
$2.61-3.40$ & Helmsman \\
$3.41-4.20$ & Coaching \\
$4.21-$ Max & Visionary \\
Min-1.80 & Dimension: Leadership Styles \\
$1.81-2.60$ & Dimension: Leadership Skills \\
$2.61-3.40$ & Deficient leadership skills. \\
$3.41-4.20$ & Low leadership skills. \\
& Regular leadership skills. \\
& High leadership skills. \\
\hline
\end{tabular}

On the other hand, this type of research is descriptive since it shows the information extracted from observable elements in a variable, the female leadership. The small and medium companies under study have begun to apply equality approaches with regards to women, recognizing their competences without gender discrimination. Thus, from a 
legal point of view, the principle of equality has gained space and it involves important changes in women rights and in their ability to assume challenges in the effective and efficient managerial performance of business.

For the above reasons, we have chosen to measure the data on the female leadership behavior variable, considering the following dimensions: styles, skills, and characteristics. The population is composed of 110,012 eradicated women, based on data from the National Administrative Department of Statistics (DANE-2019). A probabilistic sampling technique has been applied, with a margin of error of $5 \%$ and a confidence level of $95 \%$. The sample consists of a total of 383 Wayuu women entrepreneurs in the Department of La Guajira, and it includes criteria such as being located in the Department of La Guajira, having more than 5 years of experience, being older than 25 years, holding a high school level of study, and having had a formal job. This information has been collected from August 2020 to January 2021.

The data have been analyzed through a descriptive statistical analysis using SPSS software, in order to determine the behavior of the variables under study. To test the hypotheses related to frequency distributions (described in Figure 2), a Chi-square statistic has been used.

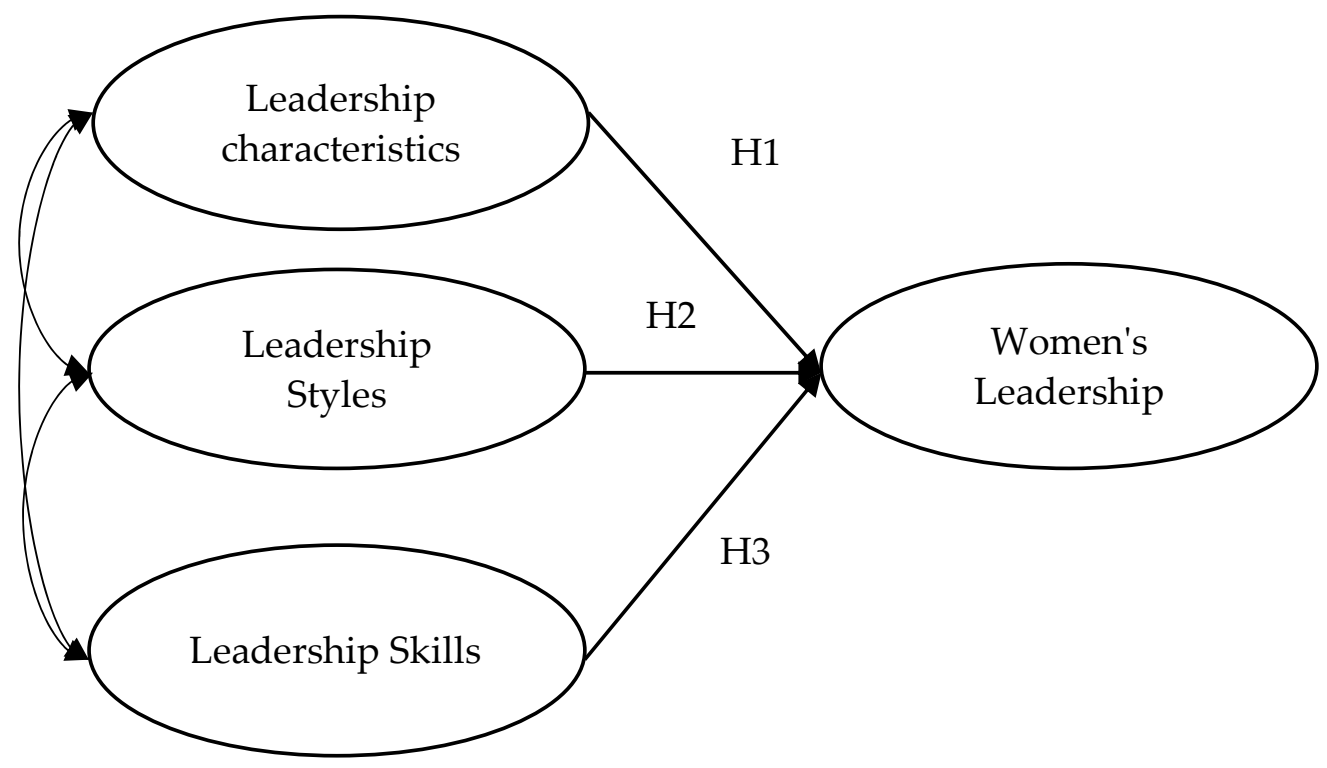

Figure 2. Research hypothesis. Source: own elaboration.

\section{Results}

The results of a research study are the product of a data analysis regarding the population under study. The interpretation of the questionnaire items has to be objective and impartial. Answers should indeed be read through a scale of interpretation of arithmetic averages (Table 2).

The female leadership variable presents a minimum of 3.48, a maximum of 4.85 , a mean of 4.179 , and a standard deviation of 0.386 . It means that for $53.3 \%$ of the 383 respondents, located in La Guajira, there is a very high presence of female leadership, while for $46.6 \%$ there is a high presence of female leadership. This implies that there are different leadership characteristics: in $39.7 \%$ of the cases, it is characterized by a coaching style based on driving processes, in $26.6 \%$ of them it is based on a participative leadership to manage SMEs, and in $23.5 \%$ of them it is characterized by Helmsman leadership. In addition, it turns out that there is a very high $(56.7 \%)$ and high $(43.3 \%)$ leadership ability. This data is high due to the answers given by the Wayuu entrepreneurs in the information exploration. 
Table 2. Descriptive statistics. Source: own elaboration.

\begin{tabular}{|c|c|c|c|c|}
\hline & Women's Leadership & Characteristics of Leaders & Leadership Styles & Leader Skills \\
\hline \multirow{7}{*}{$\begin{array}{l}\text { High presence of } \mathrm{N} \\
\text { female leadership }\end{array}$} & Valid & 179 & 179 & 179 \\
\hline & Lost & 0 & 0 & 0 \\
\hline & Mean & 5.00 & 2.58 & 4.07 \\
\hline & Median & 5.00 & 2.00 & 4.00 \\
\hline & Mode & 5 & 2 & 4 \\
\hline & Deviation & 0.000 & 0.733 & 0.260 \\
\hline & Variance & 0.000 & 0.538 & 0.068 \\
\hline \multirow{9}{*}{$\begin{array}{l}\text { Very high presence of } \\
\text { female leadership. }\end{array}$} & Valid & 204 & 204 & 204 \\
\hline & Lost & 0 & 0 & 0 \\
\hline & Mean & 5.00 & 4.00 & 5.00 \\
\hline & Median & 5.00 & 4.00 & 5.00 \\
\hline & Mode & 5 & 4 & 5 \\
\hline & Deviation & 0.000 & 0.620 & 0.000 \\
\hline & Variance & 0.000 & 0.384 & 0.000 \\
\hline & Minimum & 5 & 3 & 5 \\
\hline & Maximum & 5 & 5 & 5 \\
\hline
\end{tabular}

Figure 3 shows the existence of high leadership characteristics (above 4.0), in which there is a concentration of participative, coaching, and Helmsman leadership. The study discovers that there is a high presence of female leadership in the population under study, highlighting the rigorousness of the performance of resilient women, characterized by an empowered leadership in the management of Wayuu handicraft sales.

\section{Diagrama de cajas Agrupado de Caracteristicas de las lideres por Women's Leadership por Leadership styles}

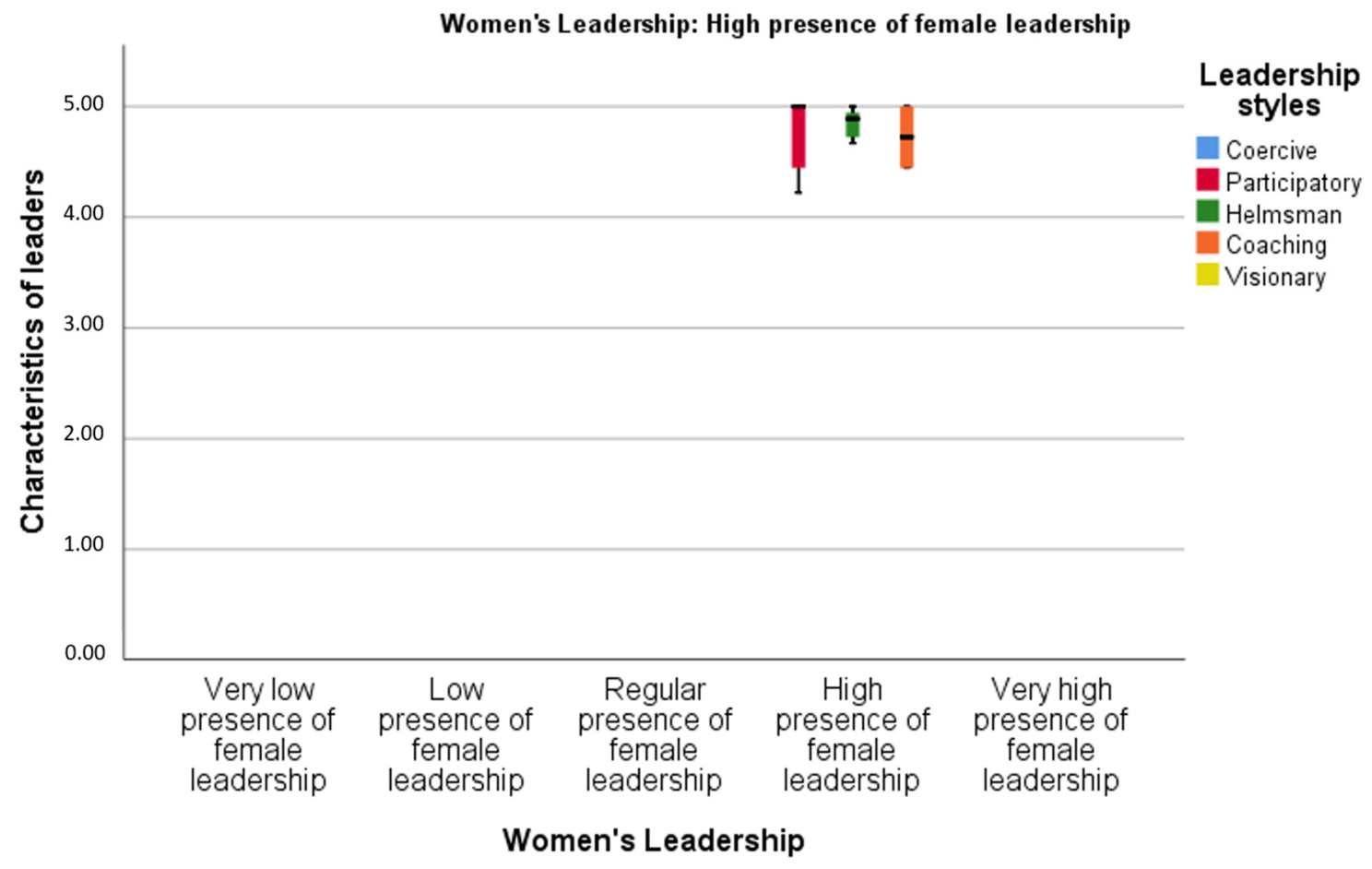

Figure 3. Women's Leadership. Source Own elaboration.

Figure 4 proposes a matrix dispersion of female leadership, on the basis of leadership styles and leader abilities (see H1). Leadership characteristics do not influence female leadership in those SMEs dedicated to the commercialization of Wayuu handicrafts. The Pearson's chi-square shows an asymptotic significance level of $0.00>0.05$; therefore, the null hypothesis is rejected, and the alternative hypothesis is accepted. In other words, it 
appears that, in the SMEs dedicated to the commercialization of Wayuu handicrafts, there is a relationship between leadership characteristics and female leadership. The intensity of the relationship through the V Cramer is 0.937.

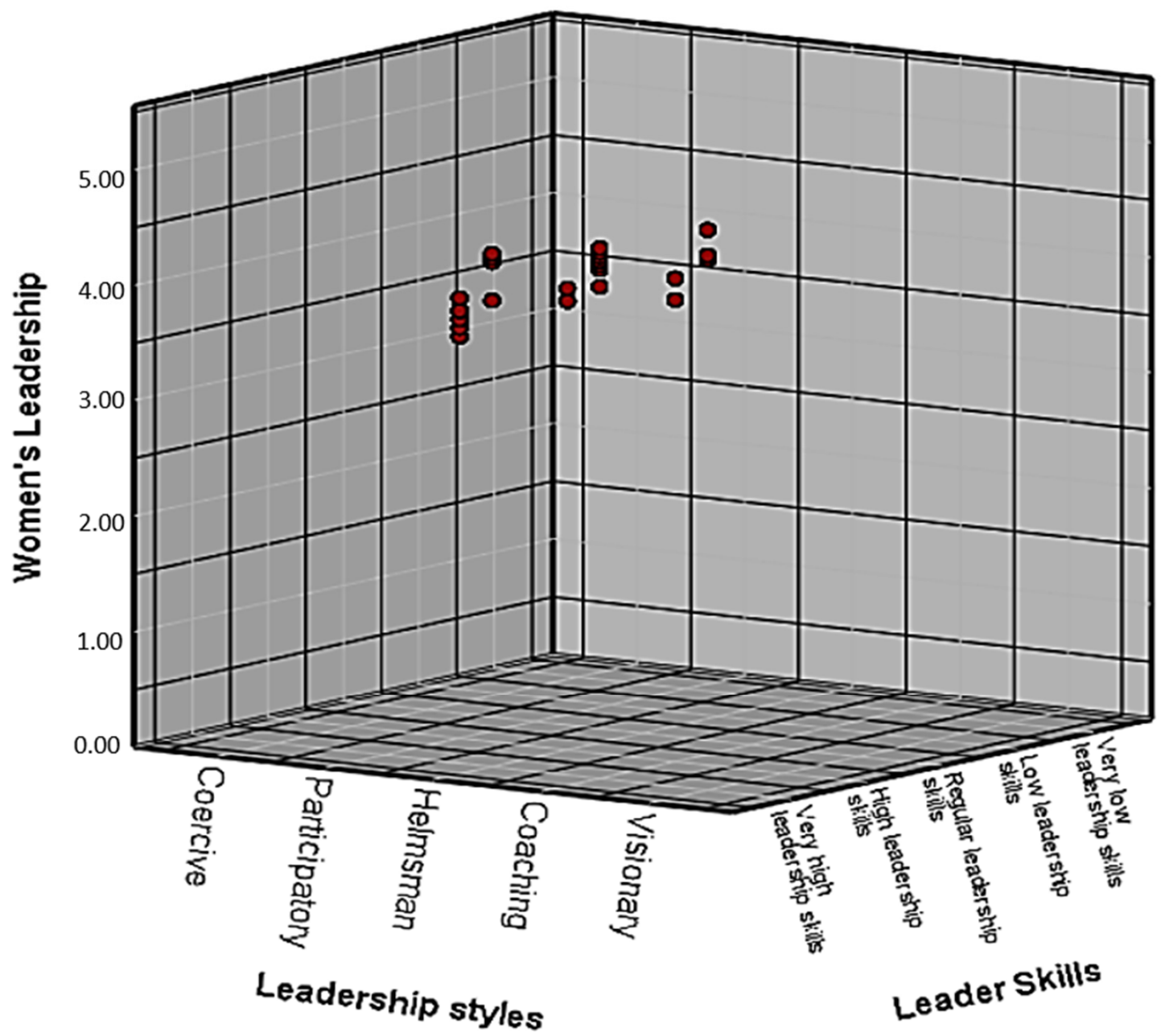

Figure 4. Filtering by variable characteristics of leaders. Source: own elaboration.

Figure 5 proposes different female leadership styles, on the basis of leadership styles and leader's capabilities (see H2). The Pearson's chi-square yields an asymptotic significance level of $0.00>0.05$; therefore, the null hypothesis is rejected, and the alternative hypothesis is accepted. In other words, in SMEs dedicated to the commercialization of Wayuu handicrafts, there is a relationship between leadership styles and female leadership. The intensity of the relationship, obtained through the V Cramer, is 0.736 (strong relationship).

Figure 6 evaluates women's leadership (H3). Leadership skills do not influence the development of female leadership in Wayuu handicraft marketing SMEs. The Pearson's chi-square yields an asymptotic significance level of $0.00>0.05$; therefore, the null hypothesis is rejected, and the alternative hypothesis is accepted. In other words, there is a relationship between leadership skills and female leadership in those SMEs related to the commercialization of Wayuu handicrafts. The intensity of the relationship through Cramer's V is 0.934 (strong relationship). 


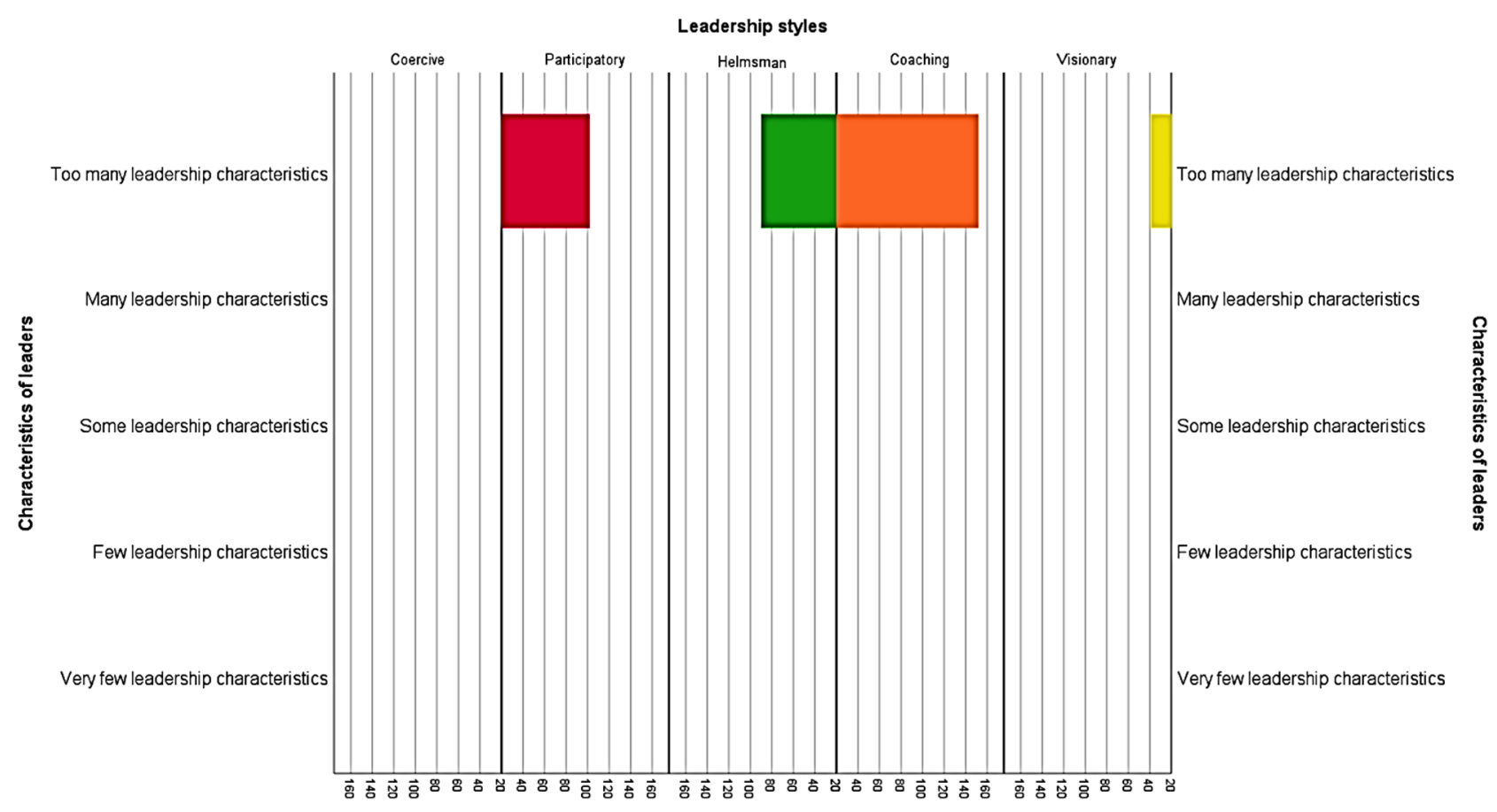

Figure 5. Leadership styles. Source: own elaboration.

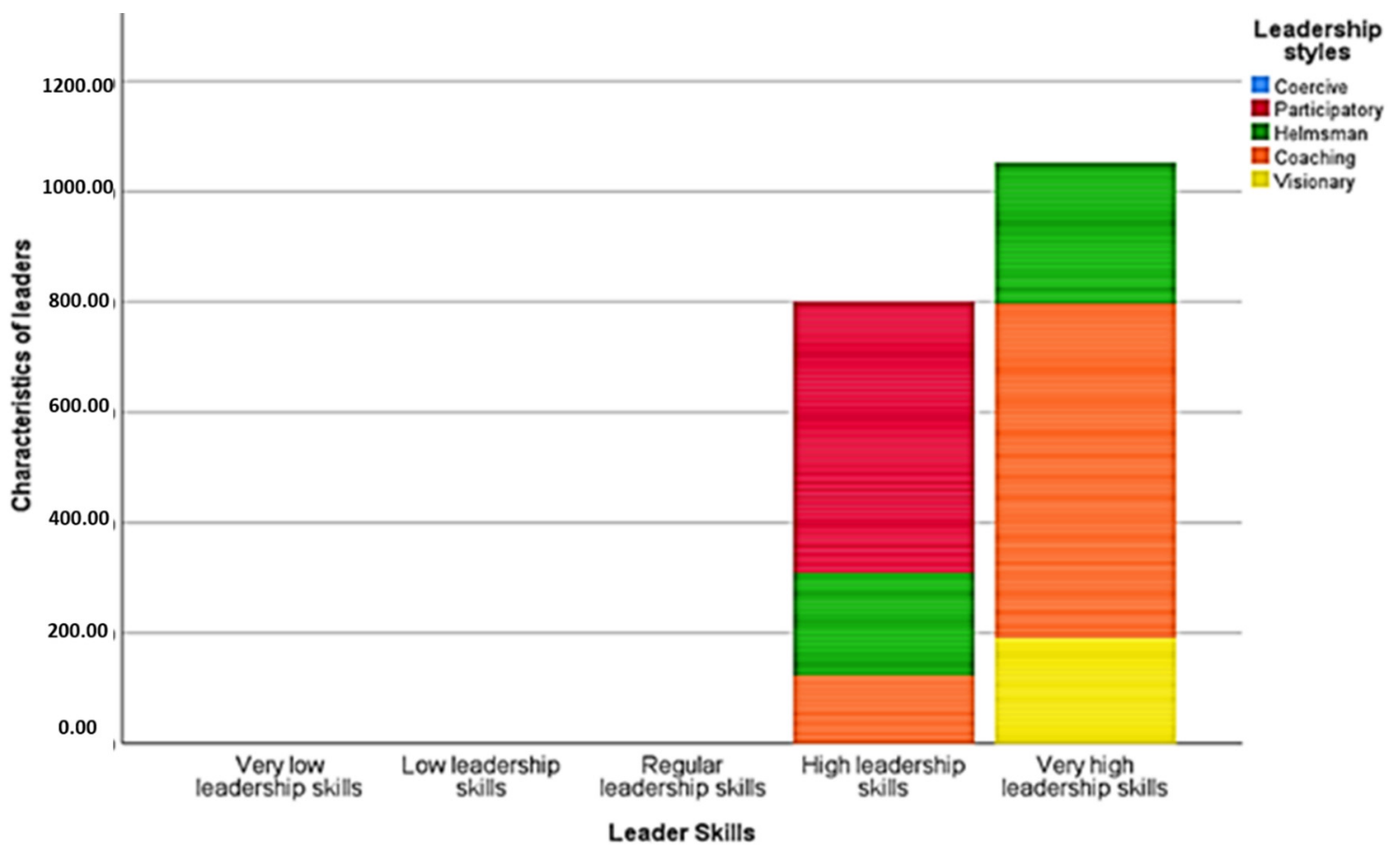

Figure 6. Filtering by variable Women's Leadership. Source: own elaboration.

\section{Discussion}

The above postulates are derived from business and academic research that analyzed women in their leadership role within companies. In this study, the female leadership variable presents a minimum and a maximum value and other statistical parameters (e.g., standard deviation). The 383 respondents are located in La Guajira, where there is a high presence of female leadership in the population under study. Leadership styles can be coercive, participative, helping, visionary, and coaching $[49,50,53]$. The rigorous performance of resilient women stands out, characterized by an empowered leadership in the management of the Wayuu handicrafts sale [56,57]. 
Women's way of thinking differs from men's on the basis of some distinctive characteristics, such as their more resilient, equanimous, consensual, and mediating sense of leadership [58]. In addition, they are characterized by their ability to propose strategies that enable them to significantly contribute to the achievement of management results in companies and to successfully contribute to the achievement of strategic and corporate sustainability objectives $[59,60]$.

Wayuu women have a receptive and participative attitude, and a multidirectional, multidimensional, more democratic, dialogic, and consensual approach to leadership, as shown in this research. In other words, this paper shows that in those SMEs dedicated to the commercialization of Wayuu handicrafts, there is a relationship between leadership characteristics and female leadership [43,46,47,61].

Many indigenous populations, such as the Wayuu one, are accustomed to humanize and identify male and female genders with meteorological phenomena, with the stars, the sun, the earth, and the moon, and with a number of elements of the native land where they coexist [62]. Thus, they assume that leadership positions are open to dialogue and to collaborative work [63], and their initiatives are characterized by respect for values and principles and by the dissemination of collective actions.

Moreover, the structures in which they act turn out to be less bureaucratic and hierarchical, characterized by the diffusion of creative and innovative initiatives. The female management style is characterized by being open, competitive, innovative, empowering, person-centered, flexible, communicative, persuasive, and with a strong perception of quality. In addition, it is less hierarchical, impersonal, and inflexible, thanks to its strong empathy and decisiveness in taking risks [7,50].

Thanks to female emotional intelligence, which is an essential managerial competence $[17,61,64]$, female leadership enables the promotion of key competencies in organizations, such as skills development, cooperation, and participation. They are able to control their own emotions, and their distinctive characteristics are self-awareness, self-control, self-motivation, and empathy, which translate into a strong ability to establish positive relationships with others. In short, thanks to their intrapersonal and interpersonal intelligence, they have a great capacity to generate healthy working relationships [65].

On the other hand, some works underline that female leadership could be a limiting factor for the fulfillment of business objectives $[66,67]$ and that the exercise of their functions could assume negative traits. Other researchers, such as [68], emphasize instead the positive perception related to female leadership, which is characterized by personal security, independence, altruism, the entrepreneurial woman capable of creating change, and the ability to transform work into a vocation.

Traditionally, male leadership has been attributed to competencies that are opposed to feminine ones and to those of human talent $[69,70]$. This style of leadership is more conditioned to the lack of security and independence in the fulfillment of work processes. Attempts to devalue or even relativize the positive valuations of female leadership appear as a way of maintaining male privileges [71]. Women, in fact, are sometimes classified by society as a delicate and sensitive gender, when in fact they can assume models or patterns of behavior usually attributable to men that prove to be more than adequate to achieve success in the labor market.

Currently, some companies located in Latin America are adopting trends that denote a modern sense of business management [72]. Being inserted in an emerging economy, they must adopt approaches capable of ensuring, in various productive sectors, work models that are able to respond to the demands of a globalized economy. Several authors [73-78] point out that leadership involves some complementary competencies, such as intellectual capacity, which is the most important of all and represents the ability to create the strategic vision of the company, the culture, the organization, and all its intangible elements. This work confirms the positive relationship between sustainability and resilience already shown in other sectors, showing the key role of female leadership in reaching this goal [79-82]. 
Technical and human competencies are necessary to create excellent relations between managers and collaborators at lower management levels [83-86]. They refer to specific skills involved in the correct performance of a roles in a technical area or in a specific function and generally describe the ability to put into practice technical and specific knowledge that is closely linked to the success related to the technical execution of the role. Therefore, their definition is variable according to the technological segment of the organization.

\section{Conclusions}

An excellent leader must be able to manage appropriate communication processes, adequately combining his or her characteristics, style, and managerial skills. The latter can be summarized as technical, human, and conceptual, and are manifested as listening, observation, and expression skills. In this way, he/she can be able to relate effectively with his/her colleagues and collaborators in order to perform his/her functions.

Our findings highlight the vital importance of female leadership in Wayuu women, demonstrating to their collaborators the competencies necessary to achieve the common good, not only for economic well-being but also for their people. What distinguishes women coming from this Colombian region is that they seek to conceive companies in a more humanized way. Thus, thanks to the consistent harmonization of the work environment and their vision of SMEs companies, it is possible to achieve excellent results and promote the integration of people within work processes, promoting spaces of coexistence to achieve the common good.

However, the study is based on a very important tourism and commercial sector in Colombia, where women are often disadvantaged with regards to men. Wayuu men, indeed, have fulfilled a variety of gender roles, which have been historically inherited from one generation to another and are rooted in their culture and social organization. This can be controversial from the perspective of Western culture. For the indigenous people who have been surveyed, the gender approach is typical of Western culture; it is not a concern to talk about equality and equity, because the indigenous people understand themselves mainly from complementarity. The above shows that an investigative interest is in process, given the limitations in this first advance and also the phenomena associated with their culture and with ancestral formation, where the man, unlike the woman, is obliged to sustain his family.

This work pays attention to an issue that is underestimated by some. Sustainable development can only be achieved when resilience, leadership, and female entrepreneurship are linked. Therefore, the case study presented on Latin America shows a positive relationship between sustainability and resilience as a key to generating economic opportunities for people that today are being neglected. Moreover, it is able to favor the development of social equity.

The study has some limitations that can be overcame in future work. The first one concerns that the work is based on only one sector, and it would be interesting to study what would happen in other ones. The second is that it is based only on women, which is an added value of this paper but a comparison with the male gender could be useful. Thirdly, the methodology used is based on non-parametric tests, and therefore other methods could be proposed to make the results more robust.

In the meantime, through the results of this research, our objective is to answer other open questions in the future. The capacity of women could allow overcoming socio-cultural barriers, which is one of the factors limiting access and development in management positions. Resilient female leadership is expressed through distinctive traits, such as the ability to be effective, efficient, disciplined, and professionally ethical. In addition, it is characterized by their collaborative and consensual behavior, openness to dialogue, and participative managerial leadership. 
Author Contributions: Conceptualization, Á.A.-D., I.D., G.S.-S., R.G.-D. and E.C.V.; methodology, Á.A.-D. and R.G.-D.; software, Á.A.-D., A.P.-M., S.M.-P. and R.G.-D.; research, Á.A.-D. and A.P.-M.; data curation, A.P.-M.; writing-original draft preparation, Á.A.-D. and G.S.-S.; writing-revising and editing, Á.A.-D.; supervision, G.C., I.D., E.C.V. and Á.A.-D.; project management, Á.A.-D., A.P.-M. and E.C.V. All authors have read and agreed to the published version of the manuscript.

Funding: The APC was partially funded by Universidad Católica de la Santísima Concepción.

Institutional Review Board Statement: Not applicable.

Informed Consent Statement: Not applicable.

Data Availability Statement: Data are available on request from the authors.

Conflicts of Interest: The authors declare no conflict of interest.

\section{References}

1. Novalbos Ruiz, J. Las Bibliotecas Públicas Españolas ante los Objetivos de Desarrollo Sostenible de las Naciones Unidas «Agenda 2030». Master's Thesis, University of Extremadura, Badajoz, Spain, 2021. Available online: http://hdl.handle.net/10662/11761 (accessed on 26 June 2021).

2. González-Díaz, R.R.; Acevedo-Duque, Á.; Salazar-Sepúlveda, G.; Castillo, D. Contributions of Subjective Well-Being and Good Living to the Contemporary Development of the Notion of Sustainable Human Development. Sustainability 2021, 13, 3298. [CrossRef]

3. Giménez, T.V. Women, defenders of equality and care for nature. iQual. Revista Género Igualdad 2021, 4, 35-59. [CrossRef]

4. Peiró, J.M.; Ayala, Y.; Tordera, N.; Lorente, L.; Rodríguez, I. Bienestar sostenible en el trabajo: Revisión y reformulación [Sustainable wellness at work: Review and reformulation]. Papeles Psicólogo 2014, 35, 5-14. Available online: http://www. papelesdelpsicologo.es (accessed on 26 June 2021).

5. Di Fabio, A.; Peiró, J.M. Human Capital Sustainability Leadership to Promote Sustainable Development and Healthy Organizations: A New Scale. Sustainability 2018, 10, 2413. [CrossRef]

6. Di Fabio, A.; Bucci, O.; Gori, A. High Entrepreneurship, Leadership, and Professionalism (HELP): Towards an integrated, empirically based perspective. Front. Psychol. 2016, 7, 1842. [CrossRef]

7. D'Adamo, I.; Lupi, G. Sustainability and Resilience after COVID-19: A Circular Premium in the Fashion Industry. Sustainability 2021, 13, 1861. [CrossRef]

8. Benites, M.; González-Díaz, R.R.; Acevedo-Duque, Á.; Becerra-Pérez, L.A.; Tristancho Cediel, G. Latin American Microentrepreneurs: Trajectories and Meanings about Informal Work. Sustainability 2021, 13, 5449. [CrossRef]

9. Joga-Elvira, L.; Jacas, C.; Joga, M.L.; Roche-Martínez, A.; Brun-Gasca, C. Pilot study of socio-emotional factors and adaptive behavior in young females with fragile $X$ syndrome. Child Neuropsychol. 2021, 1-11. [CrossRef]

10. Lee, J.; Kim, E. Would Overconfident CEOs Engage More in Environment, Social, and Governance Investments? With a Focus on Female Representation on Boards. Sustainability 2021, 13, 3373. [CrossRef]

11. Ullah, F.; Wu, Y.; Mehmood, K.; Jabeen, F.; Iftikhar, Y.; Acevedo-Duque, Á.; Kwan, H.K. Impact of Spectators' Perceptions of Corporate Social Responsibility on Regional Attachment in Sports: Three-Wave Indirect Effects of Spectators' Pride and Team Identification. Sustainability 2021, 13, 597. [CrossRef]

12. Rolinek, L.; Kopta, D.; Plevny, M.; Rost, M.; Kubecova, J. Level of process management implementation in SMEs and some related implications. Transform. Bus. Econ. 2015, 14, 360-377.

13. Caruso, G.; Gattone, S.A.; Fortuna, F.; Di Battista, T. Cluster Analysis for mixed data: An application to credit risk evaluation. Socio Econ. Plan. Sci. 2021, 73, 100850. [CrossRef]

14. Mabula, J.B.; Dongping, H.; Mwakapala, L.Y. SME's use of I.C.T. and financial services on innovation performance: The mediating role of managers' experience. Hum. Syst. Manag. 2020, 39, 427-439. [CrossRef]

15. Bajrami, D.D.; Radosavac, A.; Cimbaljević, M.; Tretiakova, T.N.; Syromiatnikova, Y.A. Determinants of 580 residents' support for sustainable tourism development: Implications for rural communities. Sustainability 2020, 12, 9438. [CrossRef]

16. Acevedo, Á.E.; Vergara, O.; González, Y. Responsible Marketing: Distinctive Advantage in the Value Chain of Organizations. J. Manag. Bus. Stud. 2019, 1, 44-74. [CrossRef]

17. Díez-Gutiérrez, E.-J.; Valle Flórez, R.E.; Terrón Bañuelos, E.; Centeno Suárez, B. El liderazgo femenino y su ejercicio en las organizaciones educativas. Iberoam. J. Educ. 2003, 33, 1-19. [CrossRef]

18. Biswas, P.K.; Roberts, H.; Stainback, K. Does women's board representation affect non-managerial gender inequality? Hum. Resour. Manag. 2021. [CrossRef]

19. Thomas, G. A typology for the case study in social science following a review of definition, discourse, and structure. Qual. Inq. 2011, 17, 511-521. [CrossRef]

20. Kadi-Montiel, O.; Acevedo-Duque, A. Liderazgo ético frente a la diversidad cultural dentro de las organizaciones con régimen disciplinario. Económicas CUC 2014, 35, 75-88. Available online: https:/ / revistascientificas.cuc.edu.co/economicascuc/article/ view/522 (accessed on 10 July 2021). 
21. González-Díaz, R.R.; Guanilo-Gómez, S.L.; Acevedo-Duque, E.; Campos, J.S.; Cachicatari Vargas, E. Intrinsic alignment with strategy as a source of business sustainability in S.M.E.s. Entrep. Sustain. Issues 2021, 8, 377-388. [CrossRef]

22. Weiner, J.M.; Cyr, D.; Burton, L.J. Microaggressions in administrator preparation programs: How black female participants experienced discussions of identity, discrimination, and leadership. J. Res. Leadersh. Educ. 2019. [CrossRef]

23. Kawai, N.; Kazumi, T. Female entrepreneurs' cognitive attributes and venture growth in Japan: The moderating role of perceived social legitimacy. Int. J. Gend. Entrep. 2021, 13. [CrossRef]

24. Müller, J.; Acevedo-Duque, Á.; Müller, S.; Kalia, P.; Mehmood, K. Predictive Sustainability Model Based on the Theory of Planned Behavior Incorporating Ecological Conscience and Moral Obligation. Sustainability 2021, 13, 4248. [CrossRef]

25. Vigil, K.M. Warrior Women: Recovering Indigenous Visions across Film and Activism. JCMS J. Cine. Media Stud. 2021, 60, 169-174. [CrossRef]

26. Russomanno, J.; Tree, J.M.J.T.J. Assessing sense of community at farmers markets. J. Agric. Food Syst. Community Dev. 2021, 10, 1-18. [CrossRef]

27. Hallinger, P.; Chatpinyakoop, C. A Bibliometric Review of Research on Higher Education for Sustainable Development, 1998-2018. Sustainability 2019, 11, 2401. [CrossRef]

28. D'Adamo, I.; Falcone, P.M.; Imbert, E.; Morone, P. A Socio-economic Indicator for EoL Strategies for Bio-based Products. Ecol. Econ. 2020, 178, 106794. [CrossRef]

29. D'Adamo, I.; Rosa, P. How Do You See Infrastructure? Green Energy to Provide Economic Growth after COVID-19. Sustainability 2020, 12, 4738. [CrossRef]

30. Paolasso, P. Desigualdad y fragmentación territorial en América Latina. J. Lat. Am. Geogr. 2020, 19, 152-162. [CrossRef]

31. Saiz-Álvarez, J.M.; Vega-Muñoz, A.; Acevedo-Duque, Á.; Castillo, D. B Corps: A Socioeconomic Approach for the COVID-19 Post-crisis. Front. Psychol. 2020, 11, 1867. [CrossRef]

32. Macaulay, B.S.; Krishnamoorthy, S. (Re)imagined Possibilities: The Resilience of the Black Woman Griot, Zeinabu irene Davis in Conversation. Fem. Media Hist. 2021, 7, 81-114. [CrossRef]

33. Vrchota, J.; Ǩehoř, P.; Marikova, M.; Pech, M. Critical Success Factors of the Project Management in Relation to Industry 4.0 for Sustainability of Projects. Sustainability 2021, 13, 281. [CrossRef]

34. Cho, Y.; Kim, S.; You, J.; Han, H.; Kim, M.; Yoon, S. How South Korean women leaders respond to their token status: Assimilation and resistance. Hum. Resour. Dev. Int. 2021, 1-24. [CrossRef]

35. Wu, H.; Perez-Lugo, M.; Garcia, C.O.; Crespo, F.G.; Castillo, A. Empowered Stakeholders: Female University Students' Leadership During the COVID-19-Triggered On-campus Evictions in Canada and the United States. Int. J. Disaster Risk Sci. 2021, 1-12. [CrossRef]

36. Francis, B.B.; Hasan, I.; Shen, Y.V.; Wu, Q. Do activist hedge funds target female CEOs? The role of CEO gender in hedge fund activism. J. Financ. Econ. 2021, 141, 372-393. [CrossRef]

37. Pastor, R.; Verge, T. The symbolic representation of women's political firsts in editorial cartoons. Fem. Media Stud. 2021, 1-16. [CrossRef]

38. Šípová-Jungová, H.; Jurgová, L.; Hemmerová, E.; Homola, J. Interaction of Tris with D.N.A. molecules and carboxylic groups on self-assembled monolayers of alkanethiols measured with surface plasmon resonance. Appl. Surf. Sci. 2021, 546, 148984. [CrossRef]

39. Cherneski, J. Zebras showing their stripes: A critical sense-making study of women C.S.R. leaders. Qual. Res. Organ. Manag. Int. J. 2021. [CrossRef]

40. Vimal, K.E.K.; Kandasamy, J.; Duque, A.A. Integrating sustainability and remanufacturing strategies by remanufacturing quality function deployment (RQFD). Environ. Dev. Sustain. 2021, 1-33. [CrossRef]

41. Osi, E.C.; Teng-Calleja, M. Women on top: The career development journey of Filipina business executives in the Philippines. Career Dev. Int. 2021. [CrossRef]

42. Eckert, S.; Assmann, K. The "ProQuote" initiative: Women journalists in Germany push to revolutionise newsroom leadership. Fem. Media Stud. 2021, 1-18. [CrossRef]

43. Xu, H.; Luke, N.; Short, S.E. Women's Political Leadership and Adult Health: Evidence from Rural and Urban China. J. Health Soc. Behav. 2021, 62, 100-118. [CrossRef] [PubMed]

44. Shahin, M.; Ilic, O.; Gonsalvez, C.; Whittle, J. The impact of a STEM-based entrepreneurship program on the entrepreneurial intention of secondary school female students. Int. Entrep. Manag. J. 2021, 1-32. [CrossRef]

45. Leschber, G. From female surgical resident to academic leaders: Challenges and pathways forward. J. Thorac. Dis. 2021, 13, 480. [CrossRef]

46. Malloy, E.; Kavussanu, M. A comparison of authentic and transformational leadership in sport. J. Appl. Soc. Psychol. 2021. [CrossRef]

47. Kolpakov, A.; Boyer, E. Examining Gender Dimensions of Leadership in International Nonprofits. Public Integr. 2021, 23, 68-81. [CrossRef]

48. Thomas, G. Michelle Bachelet's Liderazgo Femenino (Feminine Leadership) redefining political leadership in Chile's 2005 presidential campaign. Int. Fem. J. Politics 2011, 13, 63-82. [CrossRef]

49. Helming, S.; Ungermann, F.; Hierath, N.; Stricker, N.; Lanza, G. Development of a training concept for leadership 4.0 in production environments. Procedia Manuf. 2019, 31, 38-44. [CrossRef] 
50. Kotter, J.P. La Verdadera Labor de un Líder. Ed. Norma SA. Colombia. 1999. Available online: https://books.google. rs/books?hl=sr\&lr=\&id=hcleWS-2kQgC\&oi=fnd\&pg=PA39\&dq=La+verdadera+labor+de+un+1\%C3\%ADder\&ots=miNe5 HnGWS\&sig=TotyQYwi6NW6Fe8pNbqEUnAVB40\&redir_esc=y\#v=onepage\&q=La\%20verdadera\%20labor\%20de\%20un\%20 $1 \% \mathrm{C} 3 \% \mathrm{ADder} \& \mathrm{f}=$ false (accessed on 7 July 2021).

51. Fitzgerald, T. Changing the deafening silence of indigenous women's voices in educational leadership. J. Educ. Adm. 2003, 41, 9-23. [CrossRef]

52. Landa, D.; Tyson, S.A. Coercive leadership. Am. J. Political Sci. 2017, 61, 559-574. [CrossRef]

53. Ornelas, R. Water and the Indigenous Women's Leadership Project. 2011. Available online: https://digital.library.txstate.edu/ handle/10877/12841 (accessed on 7 July 2021).

54. Davies, B.; Brighouse, T. Passionate leadership. Manag. Educ. 2010, 24, 4-6. [CrossRef]

55. Berg, M.E.; Karlsen, J.T. A study of coaching leadership style practice in projects. Manag. Res. Rev. 2016, 39, 1122-1142. [CrossRef]

56. Patel, P.; Meagher, K.; El Achi, N.; Ekzayez, A.; Sullivan, R.; Bowsher, G. Having more women humanitarian leaders will help transform the humanitarian system: Challenges and opportunities for women leaders in conflict and humanitarian health. Confl. Health 2020, 14, 1-15. [CrossRef]

57. Jaffari, A.; Lee, J.; Kim, E. Variability Modeling in Software Product Line: A Systematic Literature Review. In Software Engineering in IoT, Big Data, Cloud and Mobile Computing. Studies in Computational Intelligence; Kim, H., Lee, R., Eds.; Springer: Cham, Switzerland, 2020; Volume 930. [CrossRef]

58. Acevedo-Duque, Á.; Gonzalez-Diaz, R.; Vega-Muñoz, A.; Fernández Mantilla, M.M.; Ovalles-Toledo, L.V.; Cachicatari-Vargas, E. The Role of B Companies in Tourism towards Recovery from the Crisis COVID-19 Inculcating Social Values and Responsible Entrepreneurship in Latin America. Sustainability 2021, 13, 7763. [CrossRef]

59. Lu, P.W.; Hill, S.S.; Fields, A.C.; Davids, J.S.; Melnitchouk, N. Factors associated with the professional success of female surgical department chairs: A qualitative study. JAMA Surg. 2020, 155, 1028-1033. [CrossRef]

60. Le Loarne-Lemaire, S.; Bertrand, G.; Razgallah, M.; Maalaoui, A.; Kallmuenzer, A. Women in innovation processes as a solution to climate change: A systematic literature review and an agenda for future research. Technol. Forecast. Soc. Chang. 2020, 120440. [CrossRef]

61. Flory, J.A.; Leibbrandt, A.; Rott, C.; Stoddard, O. Increasing Workplace Diversity Evidence from a Recruiting Experiment at a Fortune 500 Company. J. Hum. Resour. 2021, 56, 73-92. [CrossRef]

62. Bulmer, E.; Riera, M.; Rodríguez, R. The Importance of Sustainable Leadership amongst Female Managers in the Spanish Logistics Industry: A Cultural, Ethical and Legal Perspective. Sustainability 2021, 13, 6841. [CrossRef]

63. Burlea-Schiopoiu, A.; Mihai, L.S. An Integrated Framework on the Sustainability of SMEs. Sustainability 2019, 11, 6026. [CrossRef]

64. Miliopoulou, G.Z.; Kapareliotis, I. The toll of success: Female leaders in the "women-friendly" Greek advertising agencies. Gend. Work. Organ. 2021. [CrossRef]

65. Sterbenk, Y.; Champlin, S.; Windels, K.; Shelton, S. Is Femvertising the New Greenwashing? Examining Corporate Commitment to Gender Equality. J. Bus. Ethics 2021, 1-15. [CrossRef]

66. Bozhinov, V.; Joecks, J.; Scharfenkamp, K. Gender spillovers from supervisory boards to management boards. Manag. Decis. Econ. 2021. [CrossRef]

67. Reichert, P.; Bird, M.D.; Farber, V. Gender and entrepreneurial propensity: Risk-taking and prosocial preferences in labour market entry decisions. Soc. Enterp. J. 2021. [CrossRef]

68. Hossain, D.M.; Alam, M.S.; Mazumder, M.M.M.; Amin, A. Gender-related discourses in corporate annual reports: An exploratory study on the Bangladeshi companies. J. Account. Organ. Chang. 2021. [CrossRef]

69. Gigol, T. Gender Differences in Engagement in Unethical Pro-Organizational Behavior-Two Studies in Poland. Sustainability 2021, 13, 39. [CrossRef]

70. Schmitt, M. Women Engineers on Their Way to Leadership: The Role of Social Support Within Engineering Work Cultures. Eng. Stud. 2021, 13, 30-52. [CrossRef]

71. Siegel, R.; König, C.J.; Zobel, Y. Executive Search Consultants' Biases Against Women (or Men?). Front. Psychol. 2020, 11, 541766. [CrossRef]

72. Baldner, C.; Pierro, A. The trials of women leaders in the workforce: How a need for cognitive closure can influence acceptance of harmful gender stereotypes. Sex Roles 2019, 80, 565-577. [CrossRef]

73. Biswas, P.K.; Roberts, H.; Whiting, R.H. Female directors and C.S.R. disclosure in Bangladesh: The role of family affiliation. Meditari Account. Res. 2021. [CrossRef]

74. Alshmery, S.N.; Alqirnas, H.R.; Alyuosef, M.I. Influence of the social and economic characteristics of Saudi women on their attitudes toward empowering them in online labor market. J. Sustain. Financ. Invest. 2021, 1-15. [CrossRef]

75. Riner, A.N.; Herremans, K.M.; Neal, D.W.; Johnson-Mann, C.; Hughes, S.J.; McGuire, K.P.; Upchurch, G.R., Jr.; Trevino, J.G. Diversification of Academic Surgery, Its Leadership, and the Importance of Intersectionality. JAMA Surg. 2021. [CrossRef]

76. De Masi, S.; Słomka-Gołębiowska, A.; Paci, A. Women on boards and monitoring tasks: An empirical application of Kanter's theory. Manag. Decis. 2021. [CrossRef]

77. Uduji, J.I.; Okolo-Obasi, E.N.; Asongu, S.A. Sustaining cultural tourism through higher female participation in Nigeria: The role of corporate social responsibility in oil host communities. Int. J. Tour. Res. 2020, 22, 120-143. [CrossRef] 
78. Caruso, G.; Fortuna, F. Mediterranean diet Patterns in the Italian Population: A functional data analysis of Google Trends. Decis. Trends Soc. Syst. 2020, 63-72. [CrossRef]

79. Appolloni, A.; Colasanti, N.; Fantauzzi, C.; Fiorani, G.; Frondizi, R. Distance Learning as a Resilience Strategy during Covid-19: An Analysis of the Italian Context. Sustainability 2021, 13, 1388. [CrossRef]

80. D'Adamo, I.; González-Sánchez, R.; Medina-Salgado, M.S.; Settembre-Blundo, D. E-Commerce Calls for Cyber-Security and Sustainability: How European Citizens Look for a Trusted Online Environment. Sustainability 2021, 13, 6752. [CrossRef]

81. Giudice, F.; Caferra, R.; Morone, P. COVID-19, the Food System and the Circular Economy: Challenges and Opportunities. Sustainability 2020, 12, 7939. [CrossRef]

82. Mahmud, P.; Paul, S.K.; Azeem, A.; Chowdhury, P. Evaluating Supply Chain Collaboration Barriers in Small- and Medium-Sized Enterprises. Sustainability 2021, 13, 7449. [CrossRef]

83. Rzemieniak, M.; Wawer, M. Employer Branding in the Context of the Company's Sustainable Development Strategy from the Perspective of Gender Diversity of Generation Z. Sustainability 2021, 13, 828. [CrossRef]

84. Vega, A.; Bustamante, G.; Salazar, G. Orange Economy and Digital Entrepreneurship in Latin America: Creative Sparkles among Raw Materials, Chapter 10. In Handbook of Research on Digital Marketing Innovations in Social Entrepreneurship and Solidarity Economics; Saiz-Alvarez, J.M., Ed.; I.G.I. Global: Hershey, PA, USA, 2019; pp. 182-203. [CrossRef]

85. Molina-Ramírez, E.; Barba-Sánchez, V. Embeddedness as a Differentiating Element of Indigenous Entrepreneurship: Insights from Mexico. Sustainability 2021, 13, 2117. [CrossRef]

86. Hristov, I.; Appolloni, A.; Chirico, A.; Cheng, W. The role of the environmental dimension in the performance management system: A systematic review and conceptual framework. J. Clean. Prod. 2021, 293, 126075. [CrossRef] 